\title{
Short communication: Effect of grazing on the concentrations of total sialic acid and hexose in bovine milk
}

\author{
S. Asakuma, ${ }^{* 1}$ Y. Ueda, ${ }^{*}$ F. Akiyama, ${ }^{*}$ Y. Uemura, $†$ M. Miyaji,‡ M. Nakamura, $\S$ M. Murai,§ and T. Urashima\# \\ *Intensive Grazing Research Team, National Agricultural Research Center for Hokkaido Region, 1 Hitsujigaoka, Toyohira-ku, Sapporo, \\ Hokkaido 062-8555, Japan \\ †Ochadai Academic Production, Ochanomizu University, 2-1-1 Otsuka, Bunkyo-ku, Tokyo 112-8610, Japan \\ ¥Research Team for TMR Preparation and Feeding Technology, National Institute of Livestock and Grassland Science, 768 Senbonmatsu, \\ Nasushiobara, Tochigi 329-2793, Japan \\ §Research Team for Dairy Production using Regional Feed Resources, National Agricultural Research Center for Hokkaido Region, \\ 1 Hitsujigaoka, Toyohira-ku, Sapporo, Hokkaido 062-8555, Japan \\ \#Graduate School of Food Hygiene, Obihiro University of Agriculture and Veterinary Medicine, Inada-cho, Obihiro, Hokkaido 080-8555, Japan
}

\begin{abstract}
Sialic acid, which is located at the terminal end of glycoconjugates, is believed to have important biological functions. Its concentration in bovine milk varies depending on lactation stage and season. However, it remains unclear whether dietary factors, especially fresh forage, affect the total sialic acid concentration in milk. The purpose of the present study was to investigate the effect of grazing on the concentrations of total sialic acid and hexose in bovine milk. Six healthy dairy cows were used in a crossover design (3 cows fed fresh forage and 3 cows fed grass silage) for 2 wk. Individual milk samples were collected at 2 consecutive milkings (morning and evening) at $0,1,3,5,8,11$, and $14 \mathrm{~d}$ of the experimental period, and 2 consecutive samples in each cow were combined on each sampling day in proportion of the morning and evening milk yields. No differences in body weight, milk yield, or milk composition were observed between the 2 groups during the experimental period. The hexose concentration in milk did not differ between these groups during the experimental period. Conversely, the total sialic acid concentration in the milk of each grazing cow significantly increased at 11 and $14 \mathrm{~d}$ of the experimental period compared with that at $0 \mathrm{~d}$. In the grass silage group, the total sialic acid concentration at the end of the experimental period tended to be lower than that at $0 \mathrm{~d}$, but the decrease was not significant. These results indicate that grazing management could have increased the concentration of sialoglycoconjugates in milk. This suggests that grazing may increase the biological function of milk because it is thought that sialic acid is significant in many ways.
\end{abstract}

Key words: sialic acid, bovine milk, grazing

Received April 21, 2010.

Accepted June 2, 2010.

${ }^{1}$ Corresponding author: asakuma@affrc.go.jp
Sialic acid in bovine milk is generally located at the terminal position of various glycoconjugates, which include glycoproteins, glycolipids, and free oligosaccharides (Martín et al., 2001). Free sialic acid and sialyl glycoconjugates are believed to contribute to the defense mechanisms against infection in mammalian neonates (Idota and Kawakami, 1995; Useh et al., 2008) and to the development of the brain and central nervous system (Morgan and Winick, 1980; Duncan et al., 2009). Because of these significant effects, it is useful for the infant formula industry to investigate the concentration of sialic acid in bovine milk, which is an available resource for the separation of sialyl glycoconjugates. The composition of milk varies as a function of several factors, including cow breed, lactation stage, climate, and season of the year, as well as food source (Gacula et al., 1968; Sharma et al., 1983). This variation is also applicable for sialic acid concentration in bovine milk. The concentrations of total sialic acid and free sialylated oligosaccharide are markedly higher in bovine colostrum than in mature milk (Nakamura et al., 2003). Moreover, the chemical structures of sialyl glycoconjugates in bovine $\kappa-\mathrm{CN}$ vary during lactation (Saito and Itoh, 1992). Bovine, caprine, and ovine milks contain higher concentrations of gangliosides, which are sialic acid-containing glycolipids, in the fall compared with in other seasons, although there are no significant differences in the total sialic acid concentration in milk collected in different seasons (Puente et al., 1992, 1996). Much of the data on the concentrations of sialic acid in milk have been obtained with respect to lactation and seasonal variation. However, it remains unclear whether dietary factors affect the total sialic acid concentration in milk. The purpose of the present study was to investigate the effect of grazing on the concentrations of total sialic acid and hexose in bovine milk.

The experiment was conducted at a mixed sown pasture at the National Agriculture Research Center for 
Table 1. Ingredient and chemical compositions of total diets

\begin{tabular}{|c|c|c|c|c|c|c|c|c|}
\hline \multirow[b]{2}{*}{ Item } & \multicolumn{2}{|c|}{$\begin{array}{l}\text { Ingredient composition } \\
\text { (\% of dietary DM) }\end{array}$} & \multicolumn{6}{|c|}{$\begin{array}{l}\text { Chemical composition } \\
\text { (\% of DM unless noted) }\end{array}$} \\
\hline & $\begin{array}{l}\text { Fresh } \\
\text { forage }\end{array}$ & $\begin{array}{l}\text { Grass } \\
\text { silage }\end{array}$ & $\begin{array}{l}\mathrm{DM} \\
(\%)\end{array}$ & $\mathrm{CP}$ & $\mathrm{EE}^{1}$ & NDF & $\mathrm{ADF}$ & Ash \\
\hline Fresh grass forage & 70.9 & - & 23.3 & 17.1 & 4.4 & 51.9 & 30.5 & 8.7 \\
\hline Grass silage & 2.3 & 55.1 & 29.1 & 14.4 & 6.3 & 51.3 & 33.2 & 8.5 \\
\hline Beet pulp pellets & 7.0 & 10.1 & 92.0 & 9.8 & 0.3 & 45.0 & 25.4 & 6.5 \\
\hline Concentrate $^{2}$ & 19.8 & 34.8 & 89.0 & 19.7 & 2.8 & 17.9 & 10.3 & 4.6 \\
\hline Grass hay & - & - & 83.0 & 9.0 & 1.8 & 68.9 & 41.8 & 6.4 \\
\hline
\end{tabular}

Hokkaido region $\left(42^{\circ} 59^{\prime} \mathrm{N}, 141^{\circ} 24^{\prime} \mathrm{E}\right.$; Sapporo, Hokkaido, Japan) from June 29 to July 30, 2008. The average temperature was $19.6^{\circ} \mathrm{C}(\mathrm{SD}=1.5)$, and the average humidity was $81.5 \%(\mathrm{SD}=4.5)$ during this period. Six healthy lactating Holstein cows, approximately 100 d after calving, were assigned to 2 treatments (fresh forage and grass silage) in a crossover experiment with 2 periods of $14 \mathrm{~d}$. Two groups of 3 cows each either grazed on pasture or were fed grass silage in a free stall during the experimental periods. Two weeks before the start of this experiment, the grass silage group had been allowed to graze on pasture in a manner similar to the fresh forage group.

In the fresh forage group, cows were allowed to graze in a paddock for $24 \mathrm{~h}$, except for milking twice daily at 0830 and $1830 \mathrm{~h}$, and rested in the free stall before each milking. Cows were fed supplements in the free stall before each milking according to the Japanese Feeding Standard for Dairy Cattle (NARO, 2006) as recommended for milk-yielding dairy cows (Table 1 ). Water and mineralized salt were available at all times. After milking every morning, cows were moved to a fresh paddock. In the grass silage group, cows were housed in the free stall and were fed mainly with grass silage twice daily. The milking time and supplement calculations were performed in a manner similar to that for the fresh forage group.

The pasture comprised a flat section (2.7 ha) dominated by perennial ryegrass (Lolium perenne L.) and subdominated by white clover (Trifolium repens L.). The pasture was divided into 14 paddocks $(25 \mathrm{~m} \times 45$ $\mathrm{m}, 11.25$ area for 3 cows) using a combination of movable electric wire and permanent fencing. The forage height in each paddock was maintained at $28.6 \mathrm{~cm}$ (SD $=2.5$ ).

A double sampling technique was used to quantify pre- and postgrazing forage mass. On each day of the experimental period, 100 measurements of compressed pasture height in the pre- and postgrazing paddocks were taken using a rising plate meter. Pregrazing measurements were recorded in a paddock to be grazed the following day, and postgrazing measurements were recorded $1 \mathrm{~d}$ after 3 cows had been grazed in the paddock. Consumption of DM in each paddock was calculated using the difference between pre- and postpasture yield. Pasture yield ( $\mathrm{kg}$ of $\mathrm{DM} / \mathrm{ha}$ ) was calculated as $143.84 \times$ compressed pasture height $-735.83(P<$ $\left.0.0001 ; r^{2}=0.74\right)$.

Samples from all paddocks and supplements were collected every week and were then analyzed for DM, CP, ether extract, and ash according to AOAC (1990). Neutral detergent fiber and ADF in these samples were determined by detergent methods (Van Soest et al., 1991).

Cows were weighed for 2 consecutive days at the initiation of the experiment and at the end of each period. Body weights were recorded after milking in the morning and after the supplements were fed to the cows. Milk yields were recorded at the morning and evening milkings. Individual milk samples were collected at 2 consecutive milkings (morning and evening) at $0,1,3$, $5,8,11$, and $14 \mathrm{~d}$ of the experimental period. All milk in the teats was collected at milking. All the samples (approximately $500 \mathrm{~mL}$ ) were mixed well and were composed in proportion of the morning and evening milk yield in each cow on each sampling day. Subsamples (50 $\mathrm{mL}$ ) from each combined sample were used for determination of fat, protein, lactose, SNF, (using a MilkoScan FT 120, Foss, Hillerød, Denmark), and SCC (using a Fossomatic 90, Foss) in the final $4 \mathrm{~d}$ of each experimental period. These samples were frozen immediately at $-30^{\circ} \mathrm{C}$ until analysis. All treatments involving animals were preapproved by National Agriculture Research Center for Hokkaido Care and Use Committee.

Following appropriate dilution (1:300) of the milk samples with distilled water, the hexose concentration was determined by the phenol sulfuric acid method (490 $\mathrm{nm}$ ) using lactose as the standard (Nakamura et al., 

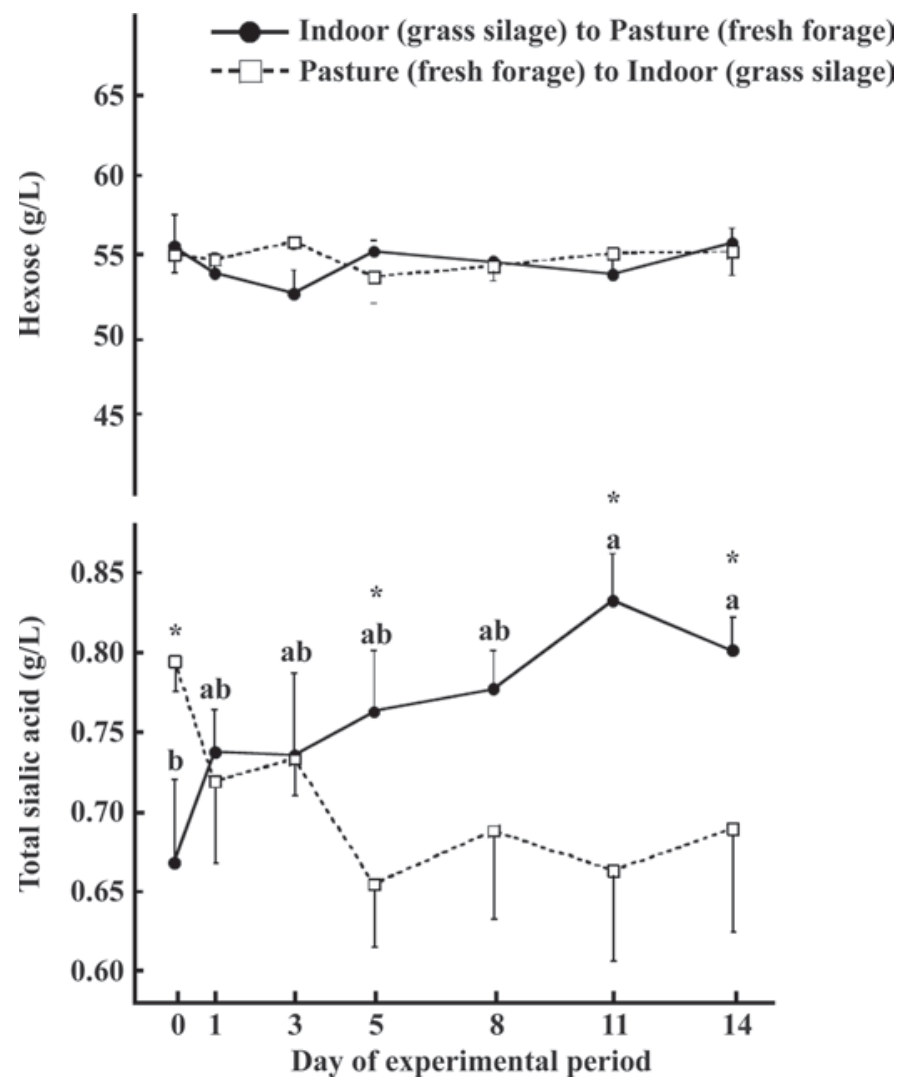

Figure 1. Variation in hexose and sialic acid concentrations in bovine milk during the experimental period. Values represent the mean \pm SEM of each treatment in experimental periods 1 and 2 . Data points with different letters differ within same treatment $(P<0.05$ by the Tukey-Kramer test). Asterisks indicate significant differences between fresh forage and grass silage group in each experimental day $(P<0.05$ by Student's $t$-test).

2003; Asakuma et al., 2008). After dilution (1:20) of the samples with water, the sialic acid concentration was determined by the colorimetric resorcinol-hydrochloric acid method $(630 \mathrm{~nm})$ using $N$-acetylneuraminic acid as the standard (Svennerholm, 1957). All milk samples were weighed for concentration correction. Data were analyzed by mixed-model analysis using JMP software (8.01, SAS Institute, Cary, NC) for a completely randomized design. The model included the fixed effect of dietary treatment and milk sampling day, the random effect of cow nested within treatment, and the residual error. Data are expressed as mean \pm standard error of the mean. The statistical difference was determined by Tukey-Kramer test in each dietary treatment and by Student's $t$-test on each milk sampling day. Difference with $P<0.05$ was considered significant.

In the present experiment, there were no differences in BW, milk yield, and milk composition between the fresh forage and grass silage groups (Table 2). There was also no difference in hexose concentrations in milk between these groups during the experimental period (Figure 1). Hexose in the milk must have been mainly composed of lactose. Many reports show that bovine milk lactose concentrations are not affected by grazing or nongrazing management (Lee et al., 2008; McEvoy et al., 2008). Our results are consistent with previous observations of lactose concentrations in the milk of grazing cows.

The total sialic acid concentration in the milk of each grazing cow significantly increased $(P=0.038)$ at 11 and $14 \mathrm{~d}$ of the experimental period compared with that at $0 \mathrm{~d}$. In the grass silage group, the total sialic acid concentration at the end of the experimental period was lower than that at $0 \mathrm{~d}$, but the decrease was not significant $(P=0.09)$. There was also a significant difference between dietary treatments $(P=0.007)$ at 0 , 5,11 , and $14 \mathrm{~d}$. Sialic acid is always present in mammalian milk; however, its concentrations vary among mammalian species (Morrissey, 1973). Sialic acid is present mainly as $N$-acetylneuraminic acid in bovine milk. Usually, sialic acid in milk is present mainly in the sialoglycoconjugated form; this conjugates with free oligosaccharides, glycoproteins, or glycolipids (gangliosides) at the terminals. These results indicate that grazing management could have increased the concentration of sialoglycoconjugates in milk.

Table 2. Body weight, milk yield, and treatment composition of the experimental period

\begin{tabular}{lcccccc}
\hline & \multicolumn{2}{c}{ Treatment } & & \multicolumn{2}{c}{ Significance $^{1}$} \\
\cline { 2 - 3 } \cline { 5 - 6 } Item & $\begin{array}{c}\text { Fresh } \\
\text { forage }\end{array}$ & $\begin{array}{c}\text { Grass } \\
\text { silage }\end{array}$ & & SEM & $P$-value \\
\hline BW $(\mathrm{kg})$ & 568.3 & 564.2 & & 7.24 & 0.78 \\
Milk yield $(\mathrm{kg} / \mathrm{d})$ & 30.55 & 32.28 & & 0.96 & 0.39 \\
Milk fat $(\%)$ & 3.62 & 3.51 & & 0.10 & 0.61 \\
Milk protein (\%) & 3.16 & 3.05 & & 0.04 & 0.23 \\
Milk lactose $(\%)$ & 4.58 & 4.66 & & 0.04 & 0.33 \\
Milk SNF $(\%)$ & 8.6 & 8.58 & & 0.06 & 0.84 \\
Milk SCC $\left(\times 10^{3}\right.$ cells $\left./ \mathrm{mL}\right)$ & 99.3 & 27.6 & & 34.2 & 0.31 \\
\hline
\end{tabular}

${ }^{1}$ There were no significant differences between fresh forage and grass silage in each parameter. 
Sutton (1989) had reported that the concentration of fat in milk can be widely altered by nutritional means; however, the concentrations of protein and lactose in milk can be only slightly altered. There is strong evidence that milk fat concentration, especially of conjugated linoleic acid, increases in the milk of grazing cows (Stockdale et al., 2003). Thus, milk glycolipid levels may also be influenced by grazing of dairy cows. Indeed, Puente et al. (1996) found that the concentration of disialoganglioside (GD3) in milk has seasonal variation, which may contribute to total sialic acid concentration.

Several studies provide evidence that certain milk proteins have immunomodulatory properties. Some milk proteins are glycoproteins that contain sialic acid (Vreeman et al., 1977; Mikkelsen et al., 2005). The sialylated glycoproteins, including $\kappa-\mathrm{CN}$ and lactoferrin $(\mathbf{L f})$, have been shown to have immunomodulatory activity. $\kappa$-Casein is a phosphorylated protein with a molecular weight of approximately $19 \mathrm{kDa}$. The glycosylated forms of $\kappa$-CN contain 0 to $5 \mathrm{~mol}$ of sialic acid/ mol of protein, and the carbohydrate moiety accounts for approximately $40 \%$ of the total $\kappa$ - $\mathrm{CN}$ molecule (Vreeman et al., 1986). Saito and Itoh (1992) suggested that $\kappa$-CN sugar chains, which contain sialic acid, include at least 3 different structures. Interestingly, they reported that the most prominent sugar chains were tetrasaccharides, which constituted $56 \%$ in milk, collected 3 mo postpartum; our samples were taken in a similar lactation period. This tetrasaccharide contains 2 molecules of sialic acid. Accordingly, the results of our study suggest that the sialylglycoconjugate of $\kappa-\mathrm{CN}$ may increase in the milk of grazing cows. Lactoferrin, which contains approximately $2 \mathrm{~mol}$ of sialic acid $/ \mathrm{mol}$ of protein, has been extensively studied for its immunostimulating properties (Steijns and van Hooijdonk, 2000). Lactoferrin concentrations in bovine milk depend on the lactation period (Law and Reiter, 1977). Recent reports have shown that $\mathrm{Lf}$ remained intact throughout ripening in raw milk cheese but not in cheeses made with pasteurized milk (Dupont et al., 2006). Moreover, Lf from human and bovine milk could be growth promoters for some bifidus flora (Petschow and Talbott, 1991; Petschow et al., 1999). If the increase in the total sialic acid concentration in this experiment was related to Lf concentration, milk provided from grazing may contribute to human health by supplying this function to dairy products.

The concentration of free oligosaccharides is lower than that of glycoproteins in mature milk (Martín et al., 2001; Martín-Sosa et al., 2003). In addition, bovine milk oligosaccharides are mainly sialylated, and their concentration is rather high in colostrum (Nakamura et al., 2003). However, this concentration is very low in transitional or mature milk (Martín-Sosa et al., 2003). The concentrations of free sialyl oligosaccharides in bovine milk also vary by season in New Zealand, where milk production occurs primarily on pasture (McJarrow and van Amelsfort-Schoonbeek, 2004). Therefore, pasture feeding of cows may increase the concentration of free sialyl oligosaccharides in milk, and this concentration varies by season.

In conclusion, we found that the total sialic acid concentration in bovine milk is affected by grazing management. Variations of sialyl conjugate concentrations in bovine milk may have been caused by feed composition. Further study is needed of the mechanism of the increase in the total sialic acid concentration in milk by grazing management.

\section{ACKNOWLEDGMENTS}

We are indebted to Nariyasu Watanabe and Kenji Sudou (Intensive Grazing Research Team, National Agricultural Research Center for Hokkaido Region, Japan) for their participation in the preparation of the manuscript. We acknowledge the supply of bovine milk samples from the dairy farm of National Agriculture Research Center for Hokkaido (Sapporo, Hokkaido, Japan). This work was supported by Grant-in-Aid for young scientists (B) (no. 20780197).

\section{REFERENCES}

AOAC. 1990. Official Methods of Analysis. 15th ed. Association of Official Analytical Chemists, Arlington, VA.

Asakuma, S., T. Urashima, M. Akahori, H. Obayashi, T. Nakamura, K. Kimura, Y. Watanabe, I. Arai, and Y. Sanai. 2008. Variation of major neutral oligosaccharides levels in human colostrum. Eur. J. Clin. Nutr. 62:488-494.

Duncan, P. I., F. Raymond, A. Fuerholz, and N. Sprenger. 2009. Sialic acid utilisation and synthesis in the neonatal rat revisited. PLoS ONE 4:e8241.

Dupont, D., C. Arnould, O. Rolet-Repecaud, G. Duboz, F. Faurie, B. Martin, and E. Beuvier. 2006. Determination of bovine lactoferrin concentrations in cheese with specific monoclonal antibodies. Int. Dairy J. 16:1081-1087.

Gacula, M. C. Jr., S. N. Gaunt, and R. A. Damon Jr.. 1968. Genetic and environmental parameters of milk constituents for five breeds. I. Effects of herd, year, season, and age of the cow. J. Dairy Sci. 51:428-437.

Idota, T., and H. Kawakami. 1995. Inhibitory effects of milk gangliosides on the adhesion of Escherichia coli to human intestinal carcinoma cells. Biosci. Biotechnol. Biochem. 59:69-72.

Law, B. A., and B. Reiter. 1977. Isolation and bacteriostatic properties of lactoferrin from bovine milk whey. J. Dairy Res. 44:595-599.

Lee, J. M., D. J. Donaghy, and J. R. Roche. 2008. Short communication: Effect of postgrazing residual pasture height on milk production. J. Dairy Sci. 91:4307-4311.

Martín, M. J., S. Martín-Sosa, L. A. Garcia-Pardo, and P. Hueso. 2001. Distribution of bovine milk sialoglycoconjugates during lactation. J. Dairy Sci. 84:995-1000.

Martín-Sosa, S., M. J. Martin, L. A. Garcia-Pardo, and P. Hueso. 2003. Sialyloligosaccharides in human and bovine milk and in infant formulas: Variations with the progression of lactation. J. Dairy Sci. 86:52-59. 
McEvoy, M., E. Kennedy, J. P. Murphy, T. M. Boland, L. Delaby, and M. O'Donovan. 2008. The effect of herbage allowance and concentrate supplementation on milk production performance and dry matter intake of spring-calving dairy cows in early lactation. J. Dairy Sci. 91:1258-1269.

McJarrow, P., and J. van Amelsfort-Schoonbeek. 2004. Bovine sialyl oligosaccharides: Seasonal variations in their concentrations in milk, and a comparison of the colostrum of Jersey and Friesian cows. Int. Dairy J. 14:571-579.

Mikkelsen, T. L., S. Bakman, E. S. Sorensen, V. Barkholt, and H. Frokiaer. 2005. Sialic acid-containing milk proteins show differential immunomodulatory activities independent of sialic acid. J. Agric. Food Chem. 53:7673-7680.

Morgan, B. L., and M. Winick. 1980. Effects of administration of Nacetylneuraminic acid (NANA) on brain NANA content and behavior. J. Nutr. 110:416-424.

Morrissey, P. A. 1973. The N-acetyl neuraminic-acid content of the milk of various species. J. Dairy Res. 40:421-425.

Nakamura, T., H. Kawase, K. Kimura, Y. Watanabe, M. Ohtani, I. Arai, and T. Urashima. 2003. Concentrations of sialyloligosaccharides in bovine colostrum and milk during the prepartum and early lactation. J. Dairy Sci. 86:1315-1320.

NARO. 2006. Japanese Feeding Standard for Dairy Cattle. National Agriculture and Food Research Organization, Japan Livestock Industry Association, Tokyo, Japan.

Petschow, B. W., and R. D. Talbott. 1991. Response of Bifidobacterium species to growth promoters in human and cow milk. Pediatr. Res. 29:208-213.

Petschow, B. W., R. D. Talbott, and R. P. Batema. 1999. Ability of lactoferrin to promote the growth of Bifidobacterium spp. in vitro is independent of receptor binding capacity and iron saturation level. J. Med. Microbiol. 48:541-549.

Puente, R., L. A. García-Pardo, R. Rueda, A. Gil, and P. Hueso 1996. Seasonal variations in the concentration of gangliosides and sialic acids in milk from different mammalian species. Int. Dairy J. $6: 315-322$

Puente, R., L. A. Garcia-Pardo, and P. Hueso. 1992. Gangliosides in bovine milk. Changes in content and distribution of individual ganglioside levels during lactation. Biol. Chem. Hoppe Seyler $373: 283-288$.

Saito, T., and T. Itoh. 1992. Variations and distributions of O-glycosidically linked sugar chains in bovine kappa-casein. J. Dairy Sci. 75:1768-1774

Sharma, A. K., L. A. Rodriguez, G. Mekonnen, C. J. Wilcox, K. C. Bachman, and R. J. Collier. 1983. Climatological and genetic effects on milk composition and yield. J. Dairy Sci. 66:119-126.

Steijns, J. M., and A. C. M. van Hooijdonk. 2000. Occurrence, structure, biochemical properties and technological characteristics of lactoferrin. Br. J. Nutr. 84:S11-S17.

Stockdale, C. R., G. P. Walker, W. J. Wales, D. E. Dalley, A. Birkett, Z. Shen, and P. T. Doyle. 2003. Influence of pasture and concentrates in the diet of grazing dairy cows on the fatty acid composition of milk. J. Dairy Res. 70:267-276.

Sutton, J. D. 1989. Altering milk-composition by feeding. J. Dairy Sci. $72: 2801-2814$

Svennerholm, L. 1957. Quantitative estimation of sialic acids. 2. A colorimetric resorcinol-hydrochloric acid method. Biochim. Biophys. Acta 24:604-611.

Useh, N. M., O. A. Olaniyan, and A. J. Nok. 2008. Comparative analysis of sialic acid levels in the colostrum and milk of ruminants: Possible role in the passive immunity against neonatal infections. Int. J. Dairy Technol. 61:253-255.

Van Soest, P. J., J. B. Robertson, and B. A. Lewis. 1991. Methods for dietary fiber, neutral detergent fiber, and nonstarch polysaccharides in relation to animal nutrition. J. Dairy Sci. 74:3583-3597.

Vreeman, H. J., P. Both, J. A. Brinkhuis, and C. van der Spek. 1977. Purification and some physicochemical properties of bovine kappacasein. Biochim. Biophys. Acta 491:93-103.

Vreeman, H. J., S. Visser, C. J. Slangen, and J. A. Van Riel. 1986. Characterization of bovine kappa-casein fractions and the kinetics of chymosin-induced macropeptide release from carbohydrate-free and carbohydrate-containing fractions determined by high-performance gel-permeation chromatography. Biochem. J. 240:87-97. 